\title{
Mathematical Critical Thinking Skills Senior High School Student Based on Mathematical Resilience and Domicile
}

\author{
Ayu Faradillah ${ }^{1}$, Tia Humaira ${ }^{2}$ \\ ${ }^{1,2}$ Mathematics Education Study Program, Faculty of Teacher Training and Education, University of Muhammadiyah Prof. Dr. \\ Hamka, \\ J1. Tanah Merdeka, East Jakarta, Indonesia \\ ayufaradillah@uhamka.ac.id
}

\begin{abstract}
The purpose of this study was to analyze students' mathematical critical thinking in terms of mathematical resilience and domicile. The method used in this research is descriptive qualitative where the process of selecting the subject uses an application called Winstep. Researchers used 473 high school students from 6 different schools to be the subjects in this study. The technique of taking the subject from research is based on the students' mathematical resilience level so there are 3 categories, namely high mathematical resilience, moderate mathematical resilience and high mathematical resilience. Data collection techniques using questionnaires, tests and interviews. Students are given a questionnaire in advance to determine the subject who will take the next test, namely mathematical critical thinking questions, after which the student's answers are analyzed and the researcher conducts interviews to find out how students solve the problems given and how many indicators the students can solve obtained in this study are students with high mathematical resilience obtain low critical thinking skills, students with moderate mathematical resilience acquire high critical thinking skills and students who have low mathematical resilience obtain moderate critical thinking skills.
\end{abstract}

Keywords: Mathematical resilience, Mathematical critical thinking, Domicile

\begin{abstract}
Abstrak
Tujuan dari penelitian ini adalah untuk menganalisis berpikir kritis matematis siswa yang ditinjau dari ketahanan matematis dan domisili. Metode yang digunakan dalam penelitian ini adalah deksriptif kualitatif dimana proses pemilihan subjek menggunakan aplikasi yang bernama Winstep. Peneliti menggunakan 473 siswa sekolah menengah atas dari 6 sekolah berbeda untuk dijadikan subjek dalam penelitian ini. Teknik pengambilan subjek dari penelitian berdasarkan tingkat ketahanan matematis siswa sehingga terdapat 3 kategori yaitu ketahanan matematis tinggi, ketahanan matematis sedang dan ketahanan matematis rendah. Teknik pengumpulan data dengan menggunakan angket, tes dan wawancara. Siswa diberikan angket terlebih dahulu untuk menentukan subjek yang akan mengikuti tes selanjutnya yaitu soal berpikir kritis matematis, setelahnya jawaban siswa dianalisis dan peneliti melakukan wawancara untuk mengetahui bagaimana siswa menyelesaikan permasalahan soal yang diberikan dan berapa indicator yang dapat di selesaikan oleh siswa. Hasil penelitian yang didapatkan dalam penelitian ini adalah siswa dengan ketahanan matematis tinggi memperoleh kemampuan berpikir kritis rendah, siswa dengan ketahanan matematis sedang memperoleh kemampuan berpikir kritis tinggi dan siswa yang memiliki ketahanan matematis rendah memperoleh kemampuan berpikir kritis sedang.
\end{abstract}

Kata kunci: Ketahanan Matematis, Berpikir kritis matematis, Domisili

Copyright (c) 2021 Ayu Faradillah, Tia Humaira

$\bowtie$ Corresponding author: Ayu Faradillah

Email Address: ayufaradillah@uhamka.ac.id (Jl. Tanah Merdeka, East Jakarta, Indonesia)

Received 09 June 2021, Accepted 05 July 2021, Published 15 July 2021

\section{INTRODUCTION}

Mathematics has a dominant function in solving problems in everyday life, because mathematics can involve various kinds of activities (Faradillah \& Febriani, 2021; Setyaningrum \& Mampouw, 2020). Students still do not understand the important role of mathematics so that they consider mathematics to be a boring and scary subject (Dwiranata et al., 2019; Nuryana \& Rosyana, 2019). So mathematical resilience is needed by students in studying mathematics. Mathematical resilience is a positive attitude of students 
when they face difficulties in learning mathematics (Kooken et al., 2015). Mathematical Resilience is one of the important aspects for the success of students in learning mathematics with many challenges, obstacles and difficulties (Muntazhimah \& Ulfah, 2020). Students who have good mathematical resilience can overcome obstacles in learning mathematics and students can work on complex math problems (Zanthy, 2018). Mathematical Resilience as a quality attitude in studying mathematics which includes confidence to get success through hard work, displaying persistence in facing difficulties or obstacles, having a desire to discuss, reflect and also research (Dilla et al., 2018). The factors that make students' mathematical resilience low such as students have a fixed mindset, are pessimistic about themselves, low self-efficacy and lack of motivation and mathematical resilience can help in seeing their intellectual abilities as something that can be developed (Lee \& Johnston-Wilder, 2017).

Intellectual ability that can be possessed by students who aim to understand a mathematical problem is mathematical critical thinking (Yanti \& Charitas, 2017). The ability to think critically in mathematics is a very important ability in life and work, besides this ability also functions effectively in all other aspects of life such as learning mathematics (Solihah, 2019). Mathematical critical thinking skills are abilities that involve prior knowledge, mathematical reasoning, and proof in mathematics (Kurniasih, 2017; Razak, 2017). Mathematical critical thinking is the student's ability to seriously analyze every action and also the action that will be taken (Imamuddin et al., 2019). Critical thinking has the goal of being able to provide indepth understanding to students (Maulidah et al., 2020). Mathematical critical thinking also provides many benefits for students such as students can improve and develop understanding of concepts and students can develop their thinking skills so that they can easily solve complex problems (Ratnawati et al., 2020). One of the obstacles that cannot encourage students' ability to think critically mathematically is the lack of curiosity that makes it difficult for students to find and think systematically, logically, critically, analytically and in formulating findings (Dwijayanti et al., 2020). By encouraging and motivating students will make students have a habit of critical thinking and can increase the effectiveness of students during learning activities at school (Hidayah et al., 2020). In addition, domicile status is also an important thing that can determine student learning activities (Kuswanto, 2016). Where students in rural areas have lower science scores than students in urban areas (Kryst et al., 2015). Students in rural areas also have lower average achievement levels than students in suburbs and schools in rural areas tend to have fewer resources than schools located in urban and suburban areas (Graham \& Provost, 2012). In this case, if education is difficult to reach, it can make students' competitiveness low and students' mindsets that are too relaxed (Gunur et al., 2018). Therefore, it takes the ability to think critically mathematically as a thinking process in analyzing an argument and generating ideas for each meaning in order to develop students' thinking patterns that make sense (Pertiwi, 2018).

There are several studies related to mathematical critical thinking. The first study was a study conducted in 2020 by Natami on students' mathematical critical thinking skills and the Adversity Question. The second research conducted in 2020 by Nidya was about mathematical critical thinking using the scientific approach. The third research conducted in 2018 by Rohaeti and Koswara on critical thinking and 
resilience using a scientific approach.

According to the relevant research above, it was found that students' critical thinking skills received a positive influence from the Adversity Question (Rahayu \& Alyani, 2020). Other research says that students' mathematical critical thinking skills can be influenced by using a scientific approach (Ucisaputri et al., 2020). Other studies say that students 'mathematical critical thinking skills will be better if learning uses the scientific approach rather than the conventional approach, but students' mathematical resilience has no difference when using the scientific approach or conventional approaches (Rohaeti \& Koswara, 2018).

Based on these 3 studies, there is a gap, namely that there is no research on the ability to think mathematically critical based on mathematical resilience and domicile. The purpose of this study was to analyze students' mathematical critical thinking in terms of mathematical resilience and domicile.

\section{METHODS}

The type of research used is a descriptive qualitative approach. Qualitative method is a research method that prioritizes in-depth understanding of a problem rather than looking at a problem for generalization research (Sandu \& Sodik, 2015). This research was conducted online through the Zoom application and Google Meet. Data collection techniques in this study were questionnaires, test questions and interviews. This questionnaire contains mathematical resilience adopted from experts (Kooken et al., 2015). This mathematical resilience questionnaire has been validated by two lecturers from the University of Muhammadiyah Prof. DR. Hamka and one teacher from the field of mathematics. The result of the validation is that the questionnaire is suitable for use, but there are improvements in wording so that students better understand the meaning of the contents of the questionnaire. Subjects in this study were selected using a Mathematical Resilience questionnaire where there were 3 categories, namely high, medium and low. Researchers also select subjects based on domicile. The following subjects have been selected:

Table 1. Subjects were selected based on Mathematical Resilience

\begin{tabular}{|c|c|c|}
\hline Category & Domicile & Code \\
\hline High & Tangerang & ST \\
\hline Medium & Jakarta & SS \\
\hline Low & Jakarta & SR \\
\hline
\end{tabular}

The test instrument used in this study aims to measure and determine the extent of students' mathematical critical thinking skills. The indicator in this test instrument is guided by (Facione, 2020). The following are indicators used in the test instrument:

Table 2. Indicator critical thinking mathematics

\begin{tabular}{|c|c|}
\hline Indicator & Sub Skill \\
\hline Interpretation & Students can write down what is stated and asked in question \\
\hline Analysis & Students can write down what to do in resolving problems \\
\hline Evaluation & Students can wrte a strategy for resolving problems \\
\hline Inference & Students can draw conclusion from what is asked correctly \\
\hline
\end{tabular}


Mathematical Critical Thinking Skills Senior High School Student Based on Mathematical Resilience and Domicile, Ayu Faradillah, Tia Humaira

Researchers also conducted interviews in this study. This interview aims to determine the student's process in taking critical thinking tests. After conducting the interview, the researcher conducted an analysis after the data collection had been completed.

\section{RESULT AND DISCUSSION}

The three selected subjects were given critical thinking test questions and after that the researchers conducted interviews with the three subjects. The results of the research will be described in accordance with the indicators of critical thinking skills. The indicator that will be described first is interpretation. In the interpretation indicator, the researcher gives two questions, one of which is as follows.

Lisa, Topik dan Bambang adalah saudara kandung. Rata-rata umur mereka bertiga
adalah 53. Umur Topik ditambah 32, sama dengan jumlah umur Lisa dan Bambang.
Umur Bambang sama dengan jumlah umur Lisa dan Topik jika dikurang 23 . Berapakah
umur Lisa, Topik dan Bambang? Interpretasikan kembali dalam bahasamu sendiri dan
dengan notasi matematika!

Figure 1. Interpretation Problem

In the matter of interpretation, ST does not solve the problem due to forgetting the material. This problem is often experienced by students, when the material has been taught the students understand and understand the material, but when new material enters students will forget the material that has been taught (Ario \& Asra, 2019). Forgetting can also be caused by students not relearning the material. In line with previous research that there are several factors for student errors in solving problems, one of which is forgetting the material that has been taught previously because students do not learn (Nugraha et al., 2019). However, SS and SR solved the problem, along with the results of SS and SR's answers:

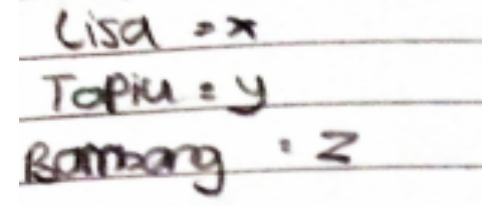

(a)

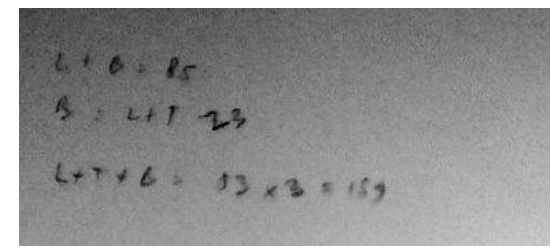

(b)

Figure 2. (a) SS answer (b) SR answers

SS only wrote down the examples in the questions, but when interviewed SS was able to interpret the questions. Following are the results of the interview with SS:

$\mathrm{R}$ : state what is known in the problem?

SS: What he knows, the average age of the three of them is 53 , then the age of the topic is the age of lisa and the whiskers plus 32 and the age of the mines is the same as the age of lisa and the topics minus 23

$\mathrm{R}$ : what was asked in that question?

SS: who were asked their respective ages

In the interview SS had an error in conveying the information that the age of Topic plus 32 should be equal to the age of Lisa and Bambang. This error is known as a reading error. Reading errors are students' inability to read information and keywords in questions (Suryanti et al., 2020). This can be caused because 
students are less careful when reading the questions. This is in line with previous research which says that reading errors can be caused by students who are not careful in reading the questions (Fatahillah et al., 2017). Then SR did not write down the information known and asked in that question. The following is an SR interview about the interpretation of the matter:

$\mathrm{R}$ : State what is known in the problem?

SR: If lisa is taken to be $\mathrm{x}$, the topic is $\mathrm{y}$ and the $\mathrm{x}$ is $\mathrm{z}$. then $\frac{x+y+z}{3}=53$, then if $\mathrm{y}$ plus $\mathrm{z}$, sorry I mean if $x+32=y+z$ and $z=y+x-23$

$\mathrm{R}$ : What was asked in that question?

SR: $y, x$ and $z$ or lisa age, topic and symbol

R: In that case, which sentence did you not understand?

SR: Actually, I do not understand the meaning of the age of the topic plus 32, which is the same as the number of ages of Lisa and Bambang. The age of the Bambang is the same as the total age of Lisa and Topics if it is subtracted from 32 .

Based on the interview, SR also did not understand the meaning in the question so that SR did not understand what was known in the question. It can be interpreted that students have difficulty in aspects of language where students find it difficult to understand and interpret the questions and students cannot retell the meaning of the questions in their own language (Dila \& Zanthy, 2020). In previous studies that the cause of this error can also be caused because students cannot understand the meaning of the sentence in the question (Suryanti et al., 2020).

Next is the analysis indicator. In the analysis indicator, the researcher also gave two questions for the subject, one of which was as follows.

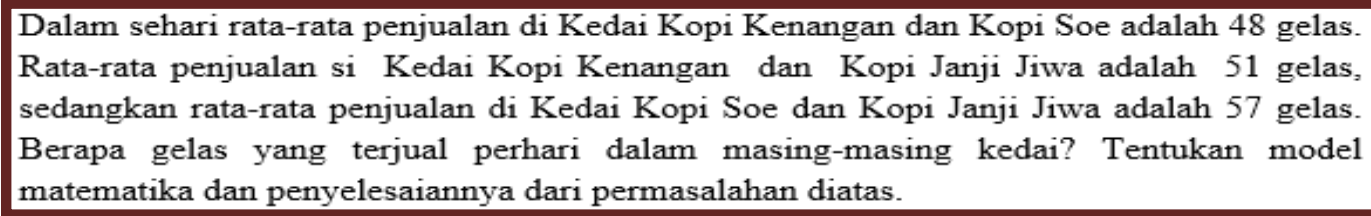

Figure 3. Analysis Problem

In the ST analysis problem also did not solve the analysis problem. When interviewed regarding the mathematical notation ST did not know which would be the mathematical notation or ST did not understand the example in the story problem. In other words, students have difficulty making representations or mathematical models of the relevant information contained in story problems (Pradini et al., 2020). In line with other studies that students' difficulties in solving story problems, one of which is modeling story questions into mathematical or illustration forms that have meaning related to the given problem (Aini et al., 2017). SS and SR can work on the problem. The following are the results of the answers from SS and SR: 


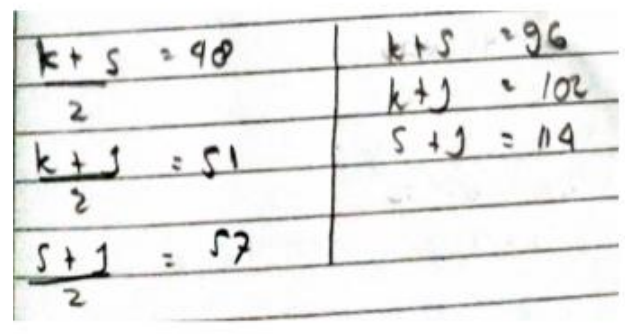

(a)

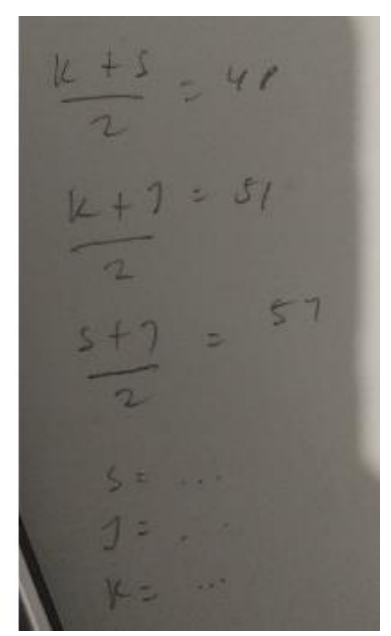

(b)

Figure 4. (a) SS answer (b) SR answers

It can be seen from the picture above that both of them can make mathematical models well. When conducting an interview with SS, SS can provide a good explanation, as follows:

$\mathrm{R}$ : State the mathematical model of the problem.

SS: So, the memory coffee shop + the soe coffee shop $=48$ glasses is double so that is multiplied by 2 the result is 96, then the memory coffee shop and the soul promise coffee shop is 51 cups times 2 again the result is 102 and Soe coffee and the soul promise 57 times 2 again the result is 114

With this SS can explain the mathematical model well. In this case students have good verbal skills that can help students understand meaning and also in making mathematical models to solve math problems (Daniyati \& Sugiman, 2015). In line with other studies that if students have better verbal skills, the students' ability to solve word problems is also getting better (Sarjana et al., 2020).

In addition to interviewing SS, the researcher also interviewed SR regarding the analysis questions, here are the results of the interview:

R: State the mathematical model of the problem.

SR: You replace your memory coffee with $\mathrm{k}$, then you replace soe coffee, then $\frac{k+s}{2}=48$, then $\mathrm{k}$ and copy the soul promise replaced $\mathrm{j}, \frac{k+j}{2}=51$, then the last one $\frac{s+j}{2}=57$

In this case, SR can make a mathematical model appropriately and can understand the problems of the problem. Students who can understand problems can make it easier for students to change situations related to everyday life into abstract equations that use mathematical symbols that can lead to mathematical models (Sarjana et al., 2020). If students can make mathematical models well, students can continue to solve problems in the problem. In line with previous research that the mathematical model that has been obtained can be used to solve mathematical problems that have been given (Pitriani, 2016).

Next is the evaluation indicator. In the evaluation indicator, the researcher also gave two questions for the subject, one of which was as follows. 
Masa kehamilan dari paus, hiu dan duyung adalah 1507 hari. Dua kali masa kehamilan duyung kemudian dikurangi 59 merupakan masa kehamilan hiu. Masa kehamilan paus 86 hari lebih lama daripada duyung. Berapakah masa kehamilan paus, hiu dan duyung? Strategi apakah yang Anda akan gunakan untuk menyelesaikan permasalahan tersebut? Jelaskan.

Figure 5. Evaluation Problem

In the analysis problem, only the SR did it, here are the results of the SR work:

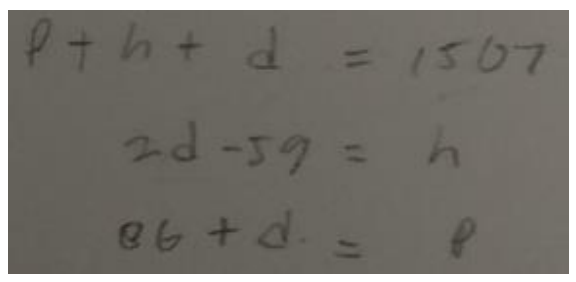

Figure 6. SR's answer

It can be seen from the picture above that SR cannot solve the problem. SR only completed at the mathematical model stage because students forgot and students could not recall the material they had previously obtained at school. If information such as a mathematical object is called repeatedly from the memory system, the information will be remembered more in our memory, but if the information is not repeated, the information can easily be lost from the information system or can be called forgotten (Ratumanan \& Laurens, 2016). This is because students do not get used to repeating lessons at home. In line with previous research that most students rarely repeat learning at home and some only repeat learning at home if there is homework (Ferryansyah et al., 2020). While ST did not do it because ST misunderstood the material, ST considered this material to be linear programming material because for him it was almost similar to the material. Mathematics has a hierarchical nature which means that in the learning process mathematics has interrelated concepts between one material and another (Fatmahanik, 2018). It can be said that students experience misconceptions. This is in line with previous research that the formation of mathematical conceptions takes place in a hierarchical manner, namely a certain stage cannot be achieved if the previous stages are not passed properly and this results in the emergence of misconceptions that make students not understand mathematical concepts (Kusaeri, 2017). Then SS did not do it because in this problem SS could not translate it into a mathematical model, following an interview with SS:

$\mathrm{R}$ : Sentences you do not understand?

SS: You understand the sentence, but I do not know how to do it because I'm confused about the mathematical model.

In the interview, SS admitted that he could not make a mathematical model. In this case the subject is able to understand the problem of the problem, but the subject cannot compile a mathematical model as a first step in solving the problem of the problem (Saputri \& Kamsurya, 2021). This is in line with previous research which states that students have difficulties in transforming problems into mathematical models when solving story problems (Jupri \& Drijvers, 2016). 
Mathematical Critical Thinking Skills Senior High School Student Based on Mathematical Resilience and Domicile, Ayu Faradillah, Tia Humaira

Next is the inference indicator. In the inference indicator, the researcher also gives two questions for the subject, one of which is as follows.

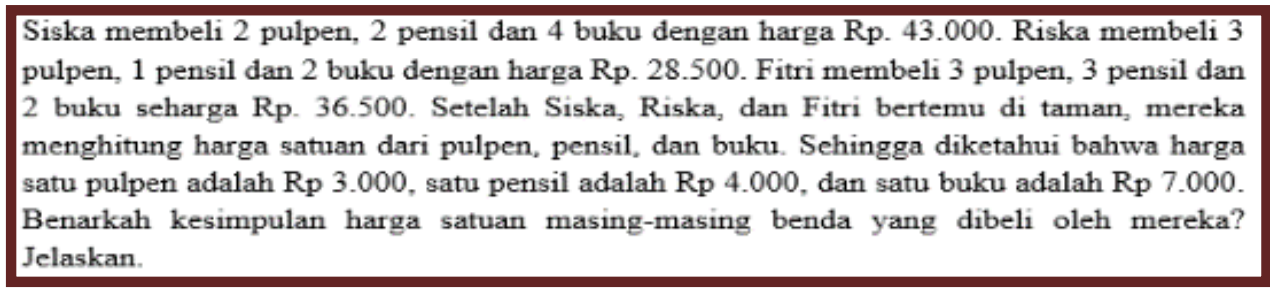

Figure 7. Inference Problem

The three subjects can answer the inference question. Here are the answers to the three subjects:

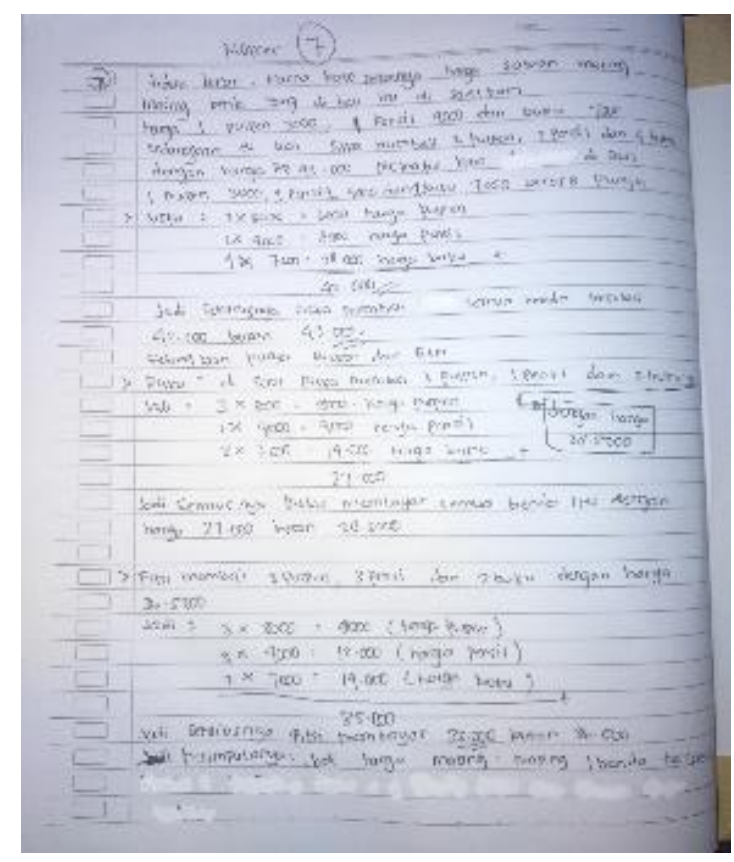

(a)
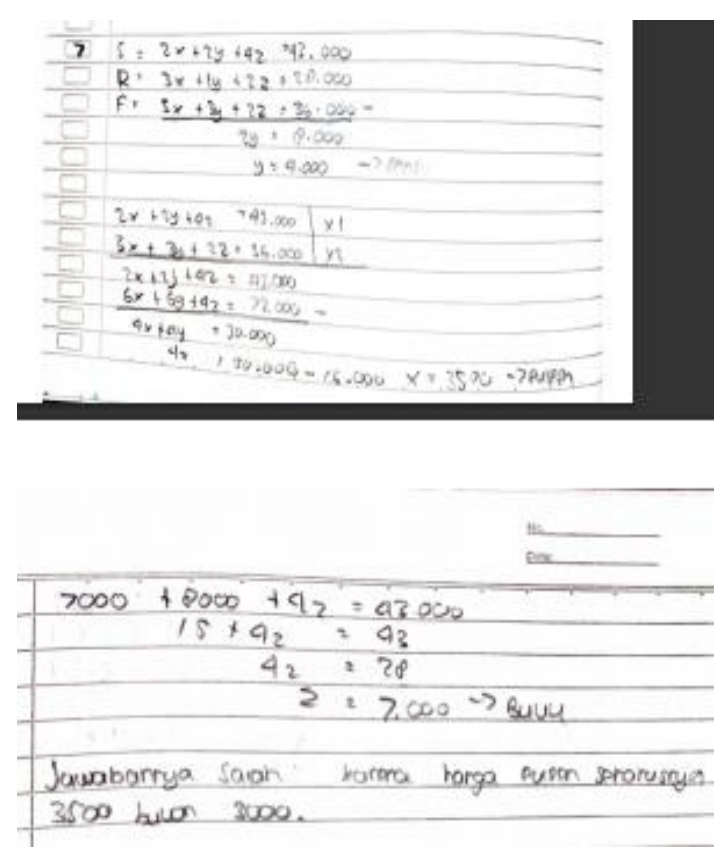

(b)

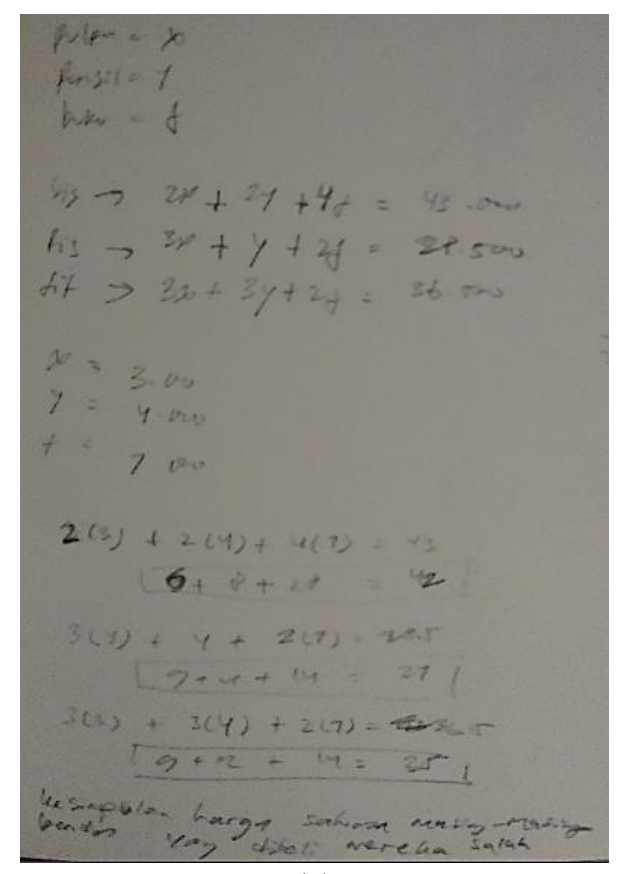

(c)

Figure 8. (a) ST answer (b) SS answer (c) SR answer 
ST can solve these problems and can make conclusions but not right because ST in solving problems does not use the right strategy. Following is the interview with ST:

$\mathrm{R}$ : The conclusion from that question?

ST: So, the price of each item is not like a problem

R: Are you sure?

ST: No.

R: Why not?

ST: because it does not use a strategy only using logic

In the interview, ST seems unable to determine the right strategy to use. In this case, ST experiences a conceptual error, one of which is an error in determining the strategy or formula to answer the problem in the question (Azis et al., 2018). In another study said that when carrying out the process of solving the problem students could not choose and use what method to use in solving the problem so that students immediately solved the problem without using the method (Wahyuni \& Widayanti, 2020).

Then SS can solve the problem and can make a conclusion, following an interview with SS:

$\mathrm{R}$ : The conclusion from that question?

SS: So, the answer is wrong in that question because the price for a pen should be 3,500, not 3000

R: You sure are right?

SS: sure

It can be seen that SS's answer was that he was not careful in reading the questions and important information in the matter, it can be seen that 3 pens, 1 pencil and 2 books were 28,500 but SS wrote 28,000. This error can include reading errors such as not being able to understand or read symbols and not understanding keywords (Sari, 2018). This result is in line with previous research that students do not interpret the sentences in the questions and also students are too quick to draw conclusions about the information contained in the questions (Setiawan et al., 2018). In fact, the ability to read questions can be a determining factor for student success in solving problem problems appropriately (Suryanti et al., 2020). SR can solve the problem, but SR does not get the actual price of each of these objects, following an interview with SR:

$\mathrm{R}$ : So, what is the conclusion from that question?

SR: I could not get the results for each item they bought, I just concluded that the unit price of each was incorrect

In this case the SR cannot conclude the problem properly because it does not use the strategy appropriately. This error can be called a process skill error where students cannot choose what strategy to use in solving the problem so that in the sequence of solutions students make mistakes because previously the students were wrong in determining the solution strategy so automatically the calculations were wrong and due to these errors the final result was wrong (Wahyuni \& Widayanti, 2020). This is in line with other studies which say that students are not used to working on problems based on steps or strategies related to 
Mathematical Critical Thinking Skills Senior High School Student Based on Mathematical Resilience and Domicile, Ayu Faradillah, Tia Humaira

questions, even students do not understand and know the formulas or strategies that will be used when solving math problems (Mafruhah \& Muchyidin, 2020).

\section{CONCLUSION}

Based on the results and discussion of the research above, it was found that ST, which has high mathematical resilience, can only answer one indicator, namely the inference indicator. However, at the inference stage, ST cannot conclude the problem from the problem correctly because during the process of solving the problem, ST does not work with the right strategy and when in the interview ST does not have confidence or it can be said that ST has doubts when asked about the problem of the question. So that ST who has high mathematical resilience gets low critical thinking skills.

SS who has moderate mathematical resilience can answer several indicators including interpretation, analysis and inference. In the SS interpretation stage, it only writes knowledge but is not accurate, the SS analysis stage can write a mathematical model correctly and can explain it well and the SS inference stage can make conclusions but there are a few mistakes. When the interview was conducted, SS seemed very confident in answering the questions the researchers asked. So that SS who has mathematical resilience is getting the ability to think highly critical.

SR which has low mathematical resilience can answer several indicators including interpretation, analysis and inference. Even though the SR can answer evaluation indicators, that is not the intention of how to solve it in evaluation indicators. In the interpretation stage, the SR only writes what it knows but it is not correct because SR does not understand the meaning in the problem, the SR analysis stage can write a mathematical model appropriately and the SR inference stage can make conclusions, but it is not correct because SR only uses logic when solving the problem. When the interview was conducted, SR seemed hesitant in answering the questions given by the researcher. So that SR who has low mathematical resilience gets the ability to think critically.

In this case it can be said that there is no influence between critical thinking skills and mathematical resilience. Therefore, teachers are expected to be able to redevelop students' mathematical critical thinking skills, such as providing questions that can familiarize students with critical thinking and teachers to cultivate students' mathematical resilience so that students can face all difficulties in solving math problems. So, in this case the researcher provides suggestions for further research to be carried out but by using different materials, different levels or indicators of critical thinking skills based on other experts such as Ennis and so on.

\section{REFERENCES}

Aini, S. D., Jannah, U. R., \& Masruroh, R. (2017). Identifikasi Kesalahan Siswa dalam Menyelesaikan $\begin{array}{lllll}\text { Masalah } & \text { Trigonometri. } & \text { Jurnal } & \text { SIGMA, }\end{array}$ http://ejournal.unira.ac.id/index.php/jurnal_sigma/article/view/337

Ario, M., \& Asra, A. (2019). Pengembangan Video Pembelajaran Materi Integral Pada Pembelajaran 
Flipped Classroom. AKSIOMA: Jurnal Program Studi Pendidikan Matematika, 8(1), 20-31. https://doi.org/10.24127/ajpm.v8i1.1709

Azis, D. M., Lukman, H. S., \& Agustiani, N. (2018). Analisis Kesalahan Siswa dalam Menyelesaikan Soal Matematika pada Materi Sistem Persamaan Linear Tiga Variabel Kelas X SMAN 1 Cisaat. Jurnal Tadris Matematika, 1(2), 193-206. https://doi.org/10.21274/jtm.2018.1.2.193-206

Daniyati, N. A., \& Sugiman, S. (2015). Hubungan Antara Kemampuan Verbal, Kemampuan Interpersonal, dan Minat Belajar dengan Prestasi Belajar Matematika. Pythagoras: Jurnal Pendidikan Matematika, 10(1), 50-60. https://doi.org/10.21831/pg.v10i1.9109

Dila, O. R., \& Zanthy, L. S. (2020). Identifikasi Kesulitan Siswa Dalam Menyelesaikan Soal Aritmatika Sosial. Teorema: Teori Dan Riset Matematika, 5(1), 17. https://doi.org/10.25157/teorema.v5i1.3036

Dilla, S. C., Hidayat, W., \& Rohaeti, E. E. (2018). Faktor Gender dan Resiliensi dalam Pencapaian Kemampuan Berpikir Kreatif Matematis Siswa SMA. Journal of Medives : Journal of Mathematics Education IKIP Veteran Semarang, 2(1), 129. https://doi.org/10.31331/medives.v2i1.553

Dwijayanti, I., Nugroho, A. A., \& Pratiwi, Y. I. (2020). Meta-Analysis: the effect of Problem Approach and Inquiry Approach Toward Students' Mathematical Critical Thinking Skill Over the Past 4 Years. AlJabar: Jurnal Pendidikan Matematika, 11(1), 101-106. https://doi.org/https://doi.org/10.24042/ajpm.v11i1.4944

Dwiranata, D., Pramita, D., \& Syaharuddin, S. (2019). Pengembangan Media Pembelajaran Matematika Interaktif Berbasis Android Pada Materi Dimensi Tiga Kelas X SMA. Jurnal Varian, 3(1), 1-5. https://doi.org/https://doi.org/10.30812/varian.v3i1.487

Facione, P. A. (2020). Critical Thinking: What It Is and Why It Counts. In Insight Assessment. https://www.insightassessment.com/article/critical-thinking-what-it-is-and-why-it-counts-pdf

Faradillah, A., \& Febriani, L. (2021). Mathematical Trauma Students' Junior High School Based on Grade and Gender. Infinity Journal, 10(1), 53. https://doi.org/10.22460/infinity.v10i1.p53-68

Fatahillah, A., Wati, Y. F., \& Susanto. (2017). Analisis Kesalahan Siswa dalam Menyelesaikan Soal Cerita Matematika Berdasarkan Tahapan Newman Beserta Bentuk Scaffolding yang Diberikan. Jurnal Kadikma, 8(1), 40-51. https://jurnal.unej.ac.id/index.php/kadikma/article/view/5229

Fatmahanik, U. (2018). Penelusuran Miskonsepsi Operasi Bilangan Bulat dalam Pembelajaran Matematika pada Mahasiswa PGMI dengan Menggunakan CRI (Certainty of Respon Index). Cendekia: Jurnal $\begin{array}{llll}\text { Kependidikan Dan } & \text { Kemasyarakatan, }\end{array}$ https://jurnal.iainponorogo.ac.id/index.php/cendekia/article/view/1201/912

Ferryansyah, F., Hermansyah, H., Widyawati, E., \& Rahayu, S. W. (2020). Klinik Matematika Sebagai Upaya Meningkatkan Minat, Motivasi, dan Kemampuan Matematika Siswa Smp Di Wilayah Perbatasan Kalimantan Utara. Jurnal Pengabdian Masyarakat Borneo, 4(1), 29-33. http://jurnal.borneo.ac.id/index.php/jpmb/article/view/1487

Graham, S. E., \& Provost, L. E. (2012). Mathematics Achievement in Kindergarten Is Lower for Rural and Urban Children and the Achievement Gap Widens by Eighth Grade. Carsey Institute, 52(52), 1-8. 
Mathematical Critical Thinking Skills Senior High School Student Based on Mathematical Resilience and Domicile, Ayu Faradillah, Tia Humaira

https://files.eric.ed.gov/fulltext/ED535962.pdf

Gunur, B., Makur, A. P., \& Ramda, A. H. (2018). Hubungan antara Kemampuan Numerik dengan Kemampuan Pemecahan Masalah Matematis Siswa di Pedesaan. MaPan, 6(2), 148-160. https://doi.org/10.24252/mapan.2018v6n2a2

Hidayah, F. N., Kusumaningsih, W., \& Prasetyowati, D. (2020). Analisis Kemampuan Berpikir Kritis Siswa SMA dalam Menyelesaikan Soal Cerita Ditinjau dari Gaya Belajar. Imajiner: Jurnal Matematika Dan Pendidikan Matematika, 2(5), 329-338. https://doi.org/10.26877/imajiner.v2i5.6477

Imamuddin, M., Fitri, H., \& Rahmadila, R. (2019). Hubungan Game Online dengan Kemampuan Berpikir Kritis Matematis Siswa Kelas VIII SMP. Jurnal Tadris Matematika, 2(1), 11-22. https://doi.org/10.21274/jtm.2019.2.1.11-22

Jupri, A., \& Drijvers, P. (2016). Student difficulties in mathematizing word problems in Algebra. Eurasia Journal of Mathematics, Science and Technology Education, 12(9), 2481-2502. https://doi.org/10.12973/eurasia.2016.1299a

Kooken, J., Welsh, M. E., McCoach, D. B., Johnston-Wilder, S., \& Lee, C. (2015). Development and Validation of the Mathematical Resilience Scale. Measurement and Evaluation in Counseling and Development, 49(3), 217-242. https://doi.org/10.1177/0748175615596782

Kryst, E. L., Kotok, S., \& Bodovski, K. (2015). Rural/urban disparities in science achievement in postsocialist countries: The evolving influence of socioeconomic status. Global Education Review, 2(4), 60-77. https://ger.mercy.edu/index.php/ger/article/view/179

Kurniasih, M. D. (2017). Penerapan Metode Inkuiri Untuk Kemampuan Berpikir Kritis Matematis Mahasiswa Calon Guru. Jurnal Euclid, 4(2), 751-760. https://doi.org/10.33603/e.v4i2.417

Kusaeri, K. (2017). Terbentuknya Konsepsi Matematika Pada Diri Anak Dari Perspektif Teori Reifikasi Dan Apos. JPM : Jurnal Pendidikan Matematika, 1(2), 101. https://doi.org/10.33474/jpm.v1i2.244

Kuswanto, K. (2016). Pengaruh Kemampuan Dasar Matematik dan Status Domisili terhadap Keberhasilan Belajar Matematika Ekonomi Mahasiswa Pendidikan Ekonomi Universitas Jambi. Edumatica : Jurnal Pendidikan Matematika, 07(02), 31-40. https://online-journal.unja.ac.id/edumatica/article/view/3701

Lee, C., \& Johnston-Wilder, S. (2017). The Construct of Mathematical Resilience. In Understanding Emotions in Mathematical Thinking and Learning. Elsevier Inc. https://doi.org/10.1016/B978-0-12802218-4.00010-8

Mafruhah, L., \& Muchyidin, A. (2020). Analisis kesalahan siswa dalam menyelesaikan soal cerita matematika berdasarkan kriteria Watson. Pythagoras: Jurnal Pendidikan Matematika, 15(1), 24-35. https://doi.org/10.21831/pg.v15i1.26534

Maulidah, E., Syaf, A. H., Rachmawati, T. K., \& Sugilar, H. (2020). Berpikir Kritis Matematis dengan Kahoot. Jurnal Analisa, 6(1), 19-27. https://doi.org/10.15575/ja.v6i1.8516

Muntazhimah, M., \& Ulfah, S. (2020). Mathematics Resilience of Pre-Service Mathematics Teacher. International Journal of Scientific and Technology Research, 9(1), 1442-1445. https://www.ijstr.org/final-print/jan2020/Mathematics-Resilience-Of-Pre-service-Mathematics- 
Teacher.pdf

Nugraha, N., Kadarisma, G., \& Setiawan, W. (2019). Analisis Kesulitan Belajar Matematika Materi Bentuk Aljabar pada Siswa SMP Kelas VII. Journal On Education, 01(02), 323-334. https://doi.org/https://doi.org/10.31004/joe.v1i2.72

Nuryana, D., \& Rosyana, T. (2019). Analisis Kesalahan Siswa SMK Dalam Menyelesaikan Soal Pemecahan Masalah Matematik Pada Materi Program Linear. Jurnal Cendekia: Jurnal Pendidikan Matematika, 3(1), 11-20. https://j-cup.org/index.php/cendekia/article/download/74/57

Pertiwi, W. (2018). Analisis Kemampuan Berpikir Kritis Matematika Peserta Didik SMK pada Materi $\begin{array}{lllll}\text { Matriks. } & \text { Jurnal } & \text { 793-801. }\end{array}$ https://jptam.org/index.php/jptam/article/view/29

Pitriani, P. (2016). Kemampuan Pemodelan Matematika dalam Realistic Mathematics Education (RME). Jurnal Edukasi Dan Sains Matematika (JES-MAT), 2(1), 65-82. https://doi.org/https://doi.org/10.25134/jes-mat.v2i1.282

Pradini, W., Muhsetyo, G., \& Rahardjo, S. (2020). Kesulitan Siswa Smp Dalam Menyelesaikan Soal Cerita Sistem Persamaan Linear Dua Variabel. Jurnal Pendidikan: Teori, Penelitian Dan Pengembangan, 5(1), 31-38. http://journal.um.ac.id/index.php/jptpp/article/view/13126

Rahayu, N., \& Alyani, F. (2020). Kemampuan Berpikir Kritis Matematis Ditinjau Dari Adversity Quotient. Prima: Jurnal Pendidikan Matematika, 4(2), 121. https://doi.org/10.31000/prima.v4i2.2668

Ratnawati, D., Handayani, I., \& Hadi, W. (2020). Pengaruh Model Pembelajaran Pbl Berbantu Question Card Terhadap Kemampuan Berpikir Kritis Matematis Siswa Smp. Edumatica : Jurnal Pendidikan Matematika, 10(01), 44-51. https://doi.org/10.22437/edumatica.v10i01.7683

Ratumanan, T. G., \& Laurens, T. (2016). Analisis Penguasaan Objek Matematika. Jurnal Pendidikan Matematika Raflesia, $1(2)$, $146-154$ https://ejournal.unib.ac.id/index.php/jpmr/article/view/4005/2221

Razak, F. (2017). Hubungan Kemampuan Awal terhadap Kemampuan Berpikir Kritis Matematis pada Siswa Kelas VII SMP Pesantren IMMIM Putri Minasatene. Mosharafa: Jurnal Pendidikan Matematika, 6(1), 117-128. https://doi.org/https://doi.org/10.31980/mosharafa.v6i1.299

Rohaeti, E. E., \& Koswara, D. (2018). Mathematical critical thinking and resiliency : Experiment of grade7 students using scientific approah. Jurnal Riset Pendidikan Matematika, 5(2), 223-232. https://doi.org/https://doi.org/10.21831/jrpm.v5i2.17322

Sandu, S., \& Sodik, M. A. (2015). Dasar Metodologi Penelitian. Literasi Media Publishing. https://zenodo.org/record/1117422\#.YHjBu-gzY5g

Saputri, V., \& Kamsurya, R. (2021). The Newman Procedure for Analyzing Students' Errors in Solving Systems of Linear Equations. Kalamatika: Jurnal Pendidikan Matematika, 6(1), 31-44. https://doi.org/10.22236/kalamatika.vol6no1.2021pp31-44

Sari, R. K. (2018). Analisis Newman dalam Menyelesaikan Soal Statistika Ditinjau dari Metakognitif Tacit Use. Jurnal Tadris Matematika, 1(2), 157-166. https://doi.org/10.21274/jtm.2018.1.2.157-166 
Mathematical Critical Thinking Skills Senior High School Student Based on Mathematical Resilience and Domicile, Ayu Faradillah, Tia Humaira

Sarjana, K., Hayati, L., \& Wahidaturrahmi, W. (2020). Mathematical modelling and verbal abilities: How they determine students' ability to solve mathematical word problems? Beta: Jurnal Tadris Matematika, 13(2), 117-129. https://doi.org/10.20414/betajtm.v13i2.390

Setiawan, Y. B., Hapizah, H., \& Hiltrimartin, C. (2018). Kesalahan Siswa dalam Menyelesaikan Soal Olimpiade SMP Konten Aljabar. Jurnal Riset Pendidikan Matematika, 5(2), 233-243. https://doi.org/10.21831/jrpm.v5i2.18191

Setyaningrum, D. U., \& Mampouw, H. L. (2020). Proses Metakognisi Siswa SMP dalam Pemecahan Masalah Perbandingan Senilai dan Berbalik Nilai Mosharafa: Jurnal Pendidikan Matematika Mosharafa : Jurnal Pendidikan Matematika. Mosharafa: Jurnal Pendidikan Matematika, 9(2), 275286. https://journal.institutpendidikan.ac.id/index.php/mosharafa/article/view/mv9n2_09/590

Solihah, S. (2019). Meningkatkan Kemampuan Berpikir Kritis Matematik Siswa MTs dengan Menggunakan Metode Brain-based Learning. TEOREMA : Teori Dan Riset Matematika, 4(1), 55-64. https://doi.org/10.25157/teorema.v4i1.1934

Suryanti, S., Sari, C. Y., \& Kristiani, K. (2020). Kesalahan Penyelesaian Soal Statistika Tipe High Order Thinking Skills Berdasarkan Teori Newman. Jurnal Tadris Matematika, 3(2), 207-218. https://doi.org/10.21274/jtm.2020.3.2.207-218

Ucisaputri, N., Nurhayati, N., \& Pagiling, S. L. (2020). Pengaruh Pendekatan Saintifik terhadap Kemampuan Berpikir Kritis Matematis pada Siswa SMP Negeri 2 Marauke. AKSIOMA: Jurnal $\begin{array}{lllll}\text { Program Studi } & \text { Pendidikan } & \text { Matematika, } & 9(3), & \text { 789-798. }\end{array}$ https://doi.org/https://doi.org/10.24127/ajpm.v9i3.2919

Wahyuni, N. S., \& Widayanti, E. (2020). Students' Errors Analysis in Finishing A Problem Solving Test Based on Newman Procedures in Trigonometry Materials. IndoMath: Indonesia Mathematics Education, 3(2), 78-87. https://doi.org/10.30738/indomath.v3i2.7213

Yanti, O. F., \& Charitas, R. C. I. (2017). Model Problem Based Learning, Guided Inquiry, Dan Kemampuan Berpikir Kritis Matematis. Jurnal Review Pembelajaran Matematika, 2(2), 120-130. https://doi.org/https://doi.org/10.15642/jrpm.2017.2.2.120-130

Zanthy, L. S. (2018). Kontribusi Resiliensi Matematis Terhadap Kemampuan Akademik Mahasiswa Pada Mata Kuliah Statistika Matematika. Mosharafa: Jurnal Pendidikan Matematika, 7(1), 85-94. https://doi.org/10.31980/mosharafa.v7i1.344 